\title{
Productive value of farmland in Gauteng with implications for land reform
}

\author{
Simon Lee (Simon.Lee@alumni.uct.ac.za) \\ David Lindeque \\ Beatrice Conradie (Beatrice.Conradie@uct.ac.za) \\ Supervisor: Beatrice Conradie \\ Department: School of Economics \\ Course: Eco3009F
}

\begin{abstract}
Information about the productive value of farmland is essential for willing buyer, willing seller land reform. We used the farm census to investigate the demand for land for two statistical regions in Gauteng over the period 1983 to 2002. With values in constant 2010 prices throughout, comparable demand curves were constructed from gross farm revenues. Although gross revenue varied from year to year and site to site, it usually fell in a band of $R 2,000$ to $R 3,000$ per hectare for this maize growing and cattle rearing area. During the study period maize production shrank by three quarters in both areas, while cattle numbers stayed constant at one site and fell by $67 \%$ at the other site. While one would expect some decline in agriculture due to urbanization, it is likely that the census no longer attains sufficient coverage to be considered a census. The minimum land reform grant can typically buy less than a hectare of farmland in this area while the maximum grant plus substantial own contribution barely achieves a farm size of thirty hectares. It is therefore unsurprising that land reform is failing.
\end{abstract}

Keywords: land reform; productive value; farmland; Gauteng 


\section{INTRODUCTION}

Land reform is a vital element of contemporary South Africa. It seeks to redress the wrongs of colonial and apartheid land policy, which has restricted $85 \%$ of South Africa's population to $15 \%$ of its land. At the end of apartheid the ANC government embarked on a three-pronged land reform project which involved redistribution, restitution and tenure reform. A redistribution goal of $30 \%$ was set for 2014 but almost no progress has been made to date. While the main objective of land reform is social justice, it has been recognized that the process should be conducted as economically efficiently as possible (Williams et al., 1998). A willing buyer willing seller model has been adopted, with grants from the Land Redistribution for Agricultural Development (LRAD) programme in the Department of Land Affairs serving as the main funding vehicle. LRAD grants are awarded on a sliding scale from R20,000 if the beneficiary makes a R5,000 contribution to R100,000 if he or she can put up R400,000 of their own capital for the project (Jacobs et al., 2003).

This paper is not about the land reform process per se. It just investigates how much land an LRAD grant could buy on the open market in Gauteng. Statistical Regions 76 (Bronkhorstspruit, Cullinan and Brits) and 78 (Pretoria, Wonderboom and Soshanguve) in Gauteng Province were used as case study. The period under consideration was 1983 to 2002.

Section 2 describes in detail how the land demand curves were constructed, purchased prices arrived at and the grant parcels calculated. The basic data tables and demand curves are presented in Section 3. The change over time in productive values and area farmed is discussed. Purchase prices are calculated for the two main enterprises at a range of discount rates and it is shown how much land can be bought with a typical LRAD grant. The paper ends with a discussion of the implications of these results for land willing buyer, willing seller land reform.

\section{METHODOLOGY}


Howe (1985) constructed a series of desktop demand curves for irrigation water for the eight sub-basins of the Upper Colorado River. He argued that farmers ought to be indifferent between farming and not farming at a net farm income per unit of water used equal the offer price for water. The same principle holds for willing buyer willing seller land reform.

The demand for farmland was calculated from the 1983, 1988, 1993 and 2002 farm censuses (Central Statistical Service, 1987, 1993, 1998; Statistics South Africa, 2002), augmented with data from Abstract of Agricultural Statistics (DAFF, 1996 \& DAFF, 2012). The coverage of the 2006 census was judged too limited to be included in this study. For the two main enterprises in our study area (beef cattle and maize growing) production costs were obtained from study group records (www.computus.co.za) and industry enterprise budgets (www.grainsa.co.za; www.nkrpo.co.za). The census data was cleaned and organized as follows:

\section{FIELD CROPS AND HORTICULTURE}

Area values were obtained directly from the various censuses. However, inconsistencies in the information regarding gross values meant that different methods of estimation were required. In order of priority, the following four methods were adopted:

A: First priority was placed on gross values explicitly stated in the census data, as is the case for all products in the 1988 and 2002 censuses.

B: Second priority was given to the average of the values obtained using methods $\mathrm{C}$ and $\mathrm{D}$.

C: Product prices are contained in the Abstract of Agricultural Statistics. Prices of field crop products for all the relevant years are provided in the 2012 Abstract of Agricultural Statistics, while horticultural product prices pre-2000 can be found in the 1996 publication. Production volumes were multiplied by average product prices to achieve estimates for gross values. For example, in 1993 the average value of potatoes was R596/ton (DAFF, 1996), and 
multiplying this figure by the volume of Potato production in 1993 for Statistical region 76 (3038 tons (Central Statistical Service, 1998)), gives a gross value estimate of approximately R181 000. Where maize prices were concerned, an average of white and yellow maize prices was used, and where wheat prices were concerned, an average of BS1 and BL1 wheat prices was used.

D: Regional production volumes were calculated as proportions of total South African production using data from the various censuses and Abstracts of Agricultural Statistics. These proportions were then multiplied by total South African values for each product, thereby providing an estimate for gross value. For example, Dry Bean production in Statistical Region 76 constituted $1.48 \%$ of total SA production in 1993 (Central Statistical Service, 1998 \& DAFF, 2012). $1.48 \%$ of total Dry Bean value in SA corresponded to an approximate gross value of R1696 000 in 1993.

\section{LIVESTOCK}

Attwood and Heavey (1964) provide Large Stock Units (LSU) for general use, showing that an individual cow is equal to $1 \mathrm{LSU}$, and a sheep or goat is equal to $1 / 6$ of a LSU. These figures were applied to the total livestock number for the whole of Gauteng in order to attain an overall LSU count for each of the relevant years. Grazing areas contained in the 1988 and 1993 censuses were divided by the total LSUs in their respective years to arrive at hectare per LSU figures. The calculations resulted in hectare per LSU figures of 1.6799 and 1.2857 in 1988 and 1993 respectively. These figures imply stocking rates that are three to four times higher than the industry consensus of five hectares per large stock unit (www.senwes.co.za; www.computus.co.za ). However, the latter is for untransformed natural rangelands, while in practice farmers usually combine natural grazing with crop residues. Multiplying the number of LSUs by the hectare per LSU values provided an estimate of the amount of land each livestock type occupies. Where there is missing data concerning livestock numbers, corresponding area estimates could not be calculated. The 1988 figure was used to estimate areas in 1983, and the 1993 figure was used to estimate areas in 2002. 
Gross values for all livestock products are included in the 1988 and 2002 censuses. This information is absent in the 1983 and 1993 editions, thus an alternative approach to gross value estimation was adopted. A proportion of overall livestock numbers was calculated by dividing regional numbers by total South African numbers in the respective years. These proportions were then applied in a number of ways according to the different livestock types. Investigation into the gross value of livestock products was limited to milk and wool. Further calculations pertaining to values of pelts, hides and other dairy products are beyond the scope of this study.

The gross value of dairy cattle was estimated by multiplying the relevant regional proportion by the overall South African production of milk, and multiplying the obtained figure by the average price of milk in the relevant year. The same procedure was carried out for wool sheep, where the price of wool was determined by a weighted average of merino and "other" wool prices, based on the sale proportions of the two types of wool in the respective years. This information is contained in the Abstract of Agricultural Statistics, 2012.

The gross values of non-dairy cattle and non-wool sheep were attained using the above procedure adapted to involve beef and mutton production and corresponding average beef and mutton prices in the relevant years. The numerous steps involved in achieving the gross value estimates for 1983 and 1993 mean that the consequential figures should be seen only as rough representations of reality.

All revenue data were converted in real 2010 values using a consumer price index (DAFF, 2012). Revenues per hectare were plotted against area utilized per crop to form a series of stepwise demand curves, one for each year and site. The statistical regions were taken as defined in 1993. Statistical Region 78 was previously known as Region 71 but comprised the same magisterial districts as the Region 78 of later censuses. Purchase prices were estimated for the two main enterprises by doing a net present value calculation over thirty years at a range of discount rates. Discount rates were obtained by calculating the real post 1994 cost of 
borrowing for agriculture as published in the Abstract of Agricultural Statistics (DAFF, 2012).

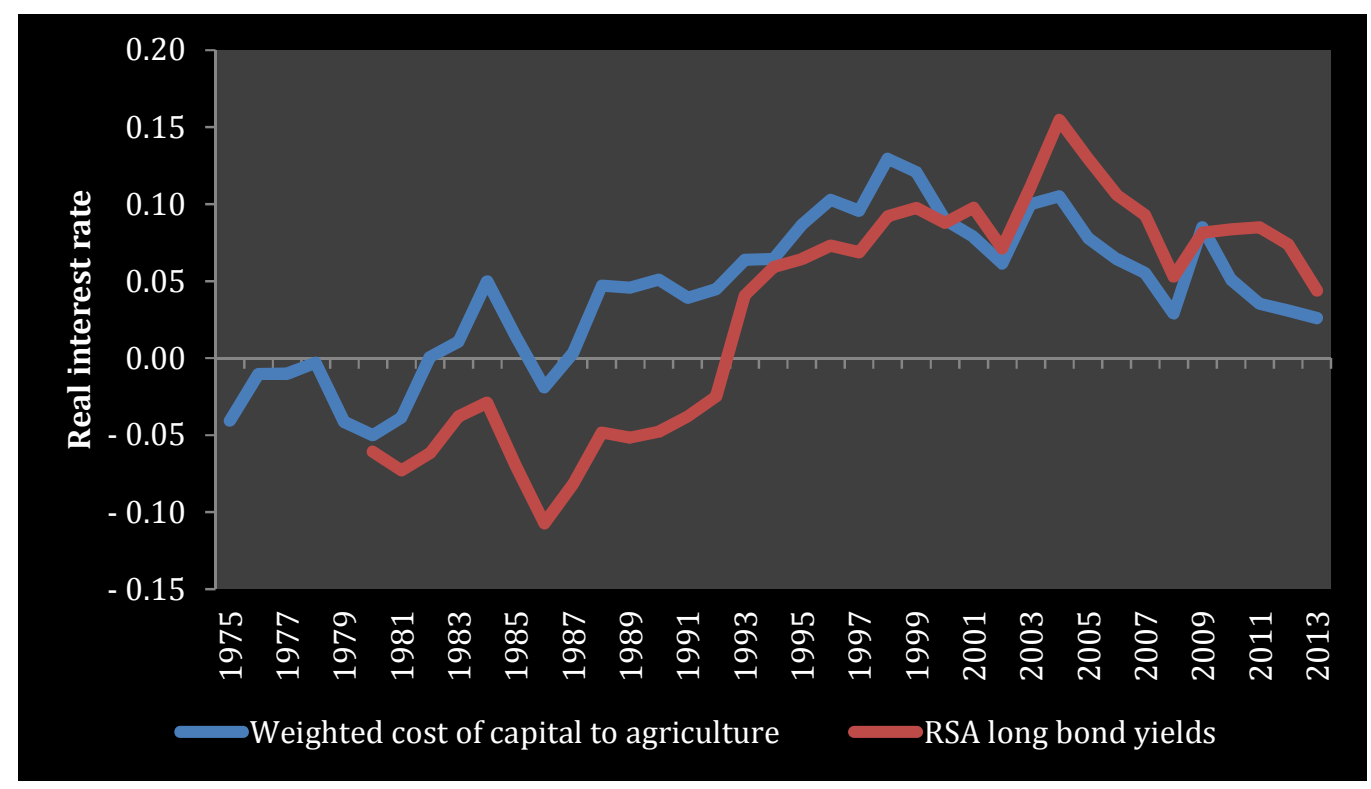

Figure 1: The opportunity cost of capital in South Africa (Source: www.daff.gov.za)

Figure 1 shows that a clear structural break in the opportunity cost of capital associated with the end of apartheid. The weighted average lending rate to agriculture has been $7.45 \pm 3.05 \%$ since 1994 , which suggested discount rates of 4.5\%, 7.5\% and 10.5\%. According to Middelberg (2014) appraisers have used rates of $12 \%$ and $15 \%$ in recent valuations, which reflect the cost of capital during the mid2000 s when bond yields were at their highest. It should be noted that higher discount rates lower the net present value of any given income stream. To take both views on board, we settled for $8 \%$ and the more politically attractive $14 \%$. The final step in the land value calculation was to calculate the total number of hectares that can be purchased with a R20,000 and R100,000 LRAD grant plus own contribution.

\section{RESULTS}

The basic data are presented in Tables 1 and 2.Table 3 contains the productive values for the main crops. Figures 2 and 3 illustrate the demand curves built from this data, while Figures 5 and 6 highlight the livestock detail. 
Table 1: Areas utilized and gross values for agricultural products in Statistical Region 78 (Source: Farm Census)

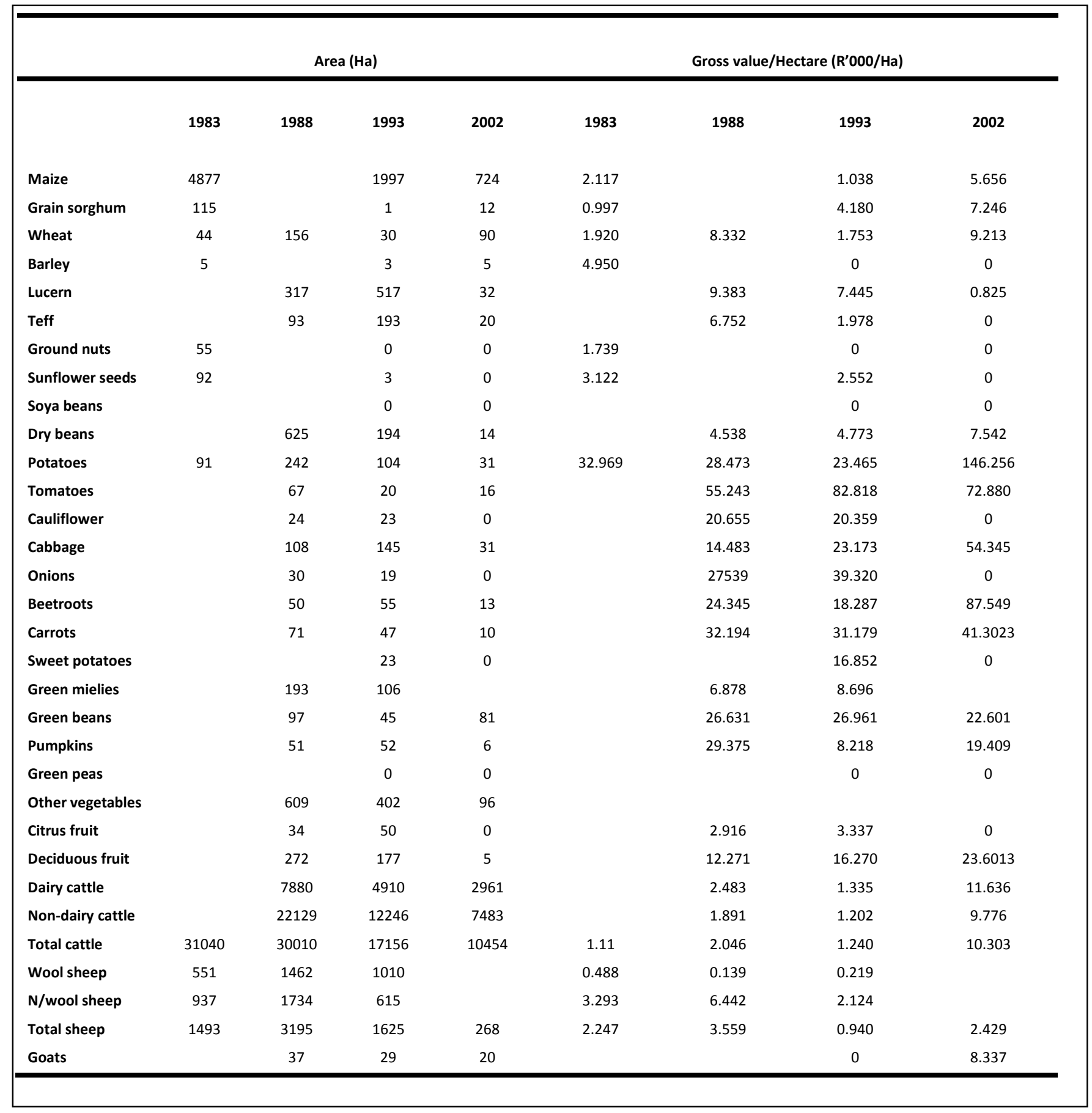


Table 2: Areas utilized and gross values for agricultural products in Statistical Region $\mathbf{7 6}$ (Source: Farm Census)

\begin{tabular}{|c|c|c|c|c|c|c|c|c|}
\hline \multirow[b]{2}{*}{ Product } & \multicolumn{4}{|c|}{ Area (Ha) } & \multicolumn{4}{|c|}{ Gross value/Hectare ( $\left.\mathrm{R}^{\prime} 000 / \mathrm{Ha}\right)$} \\
\hline & 1983 & 1988 & 1993 & 2002 & 1983 & 1988 & 1993 & 2002 \\
\hline Maize & 63827 & 43576 & 30476 & 14910 & 3.238 & 2.535 & 2.323 & 5.820 \\
\hline Grain sorghum & 746 & 326 & 258 & 29 & 4.999 & 2.957 & 1.171 & 0 \\
\hline Wheat & 9706 & 9216 & 180 & 123 & 10.330 & 3.626 & 7.583 & 7.460 \\
\hline Barley & 9 & & 0 & 5 & 3.972 & & & 0 \\
\hline Lucern & & 1114 & 1387 & 76 & & 12.370 & 0.299 & 2.595 \\
\hline Teff & & 2066 & 1138 & 388 & & 1.245 & 1.712 & 1.661 \\
\hline Ground nuts & 1767 & 1604 & 78 & 0 & 6.632 & 2.009 & 4.588 & \\
\hline Sunflower seeds & 3099 & 3022 & 1166 & 459 & 0,093 & 2.244 & 3.721 & 4.821 \\
\hline Soya beans & & 2080 & 338 & 129 & & 6.673 & 1.032 & 3.226 \\
\hline Dry beans & & 1336 & 741 & 102 & & 6.749 & 6.700 & 7.916 \\
\hline Potatoes & 80 & 298 & 124 & 109 & 42.667 & 33.897 & 42.737 & 48.932 \\
\hline Tomatoes & & 505 & 29 & 11 & & 59.834 & 81.101 & 103.044 \\
\hline Cauliflower & & 52 & 31 & 4 & & 20.337 & 46.076 & 55.122 \\
\hline Cabbage & & 647 & 150 & 21 & & 28.552 & 19.411 & 24.770 \\
\hline Onions & & 1590 & 1 & 2 & & 31.973 & 1.940 & 69.096 \\
\hline Beetroots & & 286 & 53 & 0 & & 17.371 & 39.771 & \\
\hline Carrots & & 177 & 112 & 2 & & 35786 & 38.793 & 50.463 \\
\hline Sweet potatoes & & & 43 & 2 & & & 18.223 & 13.974 \\
\hline Green mielies & & 211 & 263 & & & 7.283 & 7.537 & \\
\hline Green beans & & 386 & 42 & 6 & & 10.088 & 22.741 & 34.419 \\
\hline Pumpkins & & 579 & 40 & 22 & & 26.493 & 5.512 & 2.964 \\
\hline Green peas & & & 4 & 0 & & & & \\
\hline Other vegetables & & 1336 & 190 & 99 & & 26.348 & & \\
\hline Citrus fruit & & 1596 & 36 & 0 & & 15.830 & 5.447 & \\
\hline Deciduous fruit & & 159 & 115 & 217 & & 14.896 & 2.367 & 41.909 \\
\hline Dairy cattle & & 23893 & & 4176 & & 1.754 & 0.688 & 8.273 \\
\hline $\begin{array}{l}\text { Non-dairy cattle } \\
\text { cattle }\end{array}$ & & 128118 & & 15416 & & 3.848 & 0.206 & 1.489 \\
\hline Total cattle & 178017 & 152011 & & 19591 & 0.769 & 3.520 & 0.262 & 2.935 \\
\hline Wool sheep & 2335 & 5427 & & & 0.488 & 0.312 & 0.067 & \\
\hline N/wool sheep & 5208 & 302 & & & 3.293 & 64.306 & 1.107 & \\
\hline Total sheep & 7543 & 5730 & & 1588 & 2.424 & 3.739 & 0.341 & 6.647 \\
\hline Goats & & 365 & & 39 & & 0.136 & & 0.197 \\
\hline
\end{tabular}


http://journals.uct.ac.za/index.php/UR

DOI 10.15641/ur-at-uct.v1i1.24 
http://journals.uct.ac.za/index.php/UR

DOI 10.15641/ur-at-uct.v1i1.24 
Beef cattle rearing and maize production dominate agriculture in the study area. Other field crops include wheat, barley, grain sorghum, sunflower seeds, ground nuts, soya beans and various fodder crops, but since this category typically made up less than $10 \%$ of land use, it was not considered in calculating land values. The same was true of sheep which account for less than $5 \%$ of the farmland recorded in the census. Some horticulture occurred, including twelve types of vegetables plus deciduous fruit and citrus but in most years horticulture claimed less than $2 \%$ of the area utilized and could therefore be safely ignored as well.

The above tables and figures indicate that, relative to the area occupied by livestock and field crops, horticultural products are high value, with tomatoes regularly topping the list of valuable agricultural products. In both areas tomatoes and potatoes are the most important horticultural crop and in both locations these crops have seen fourfold real price increases since 1983. At the moment gross revenue per hectare easily amounts to R50,000 or even R100,000 per hectare per hectare for these crops. Where irrigation water permits, for example in Brits downstream of Hart041ebeespoort Dam one can expect further expansion of horticulture as these areas have a ready market for salad vegetables on its doorstep in Gauteng. However, it is unrealistic to expect the typical horticultural revenue to apply to land without irrigation rights.

In Statistical Region 76 maize's share of farmland utilized varied between 20 and $40 \%$, while cattle (including dairy) claimed between half and two-thirds of the land. In Statistical Region 78 there is less maize and more cattle; in this region maize's share of farmland varied between 6 and $9 \%$, while cattle claimed between 75 and $88 \%$ of the land utilized for agriculture. These proportions are consistent with mean gross revenue per hectare. In Statistical Region 76 maize historically brought just under R3,500 per hectare, while cattle historically produced less than R2,000 per hectare. In Statistical Region 78, the expected income from cattle grazing (in 2010 prices) is more than $\mathrm{R} 3,600$ while maize is expected to bring about $\mathrm{R} 3,000$ per hectare. See Table 3 for details. Together these two crops made up at least $80 \%$ and sometimes more than $90 \%$ of farmland utilized in the study area. These are therefore reasonable enterprises to focus on for land reform planning. 
Over the time considered, maize production shrank by three quarters in both areas. The area utilized for cattle grazing has remained approximately constant in Statistical Region 76 but decreased by two thirds in Statistical Region 78. In Statistical Region 76 total land utilized decreased by $13 \%$ between 1983 and 1988 and then by a massive 84\% between 1988 and 1993. In the period between 1993 and 2002 there was a $3 \%$ increase in the area farmed at this site. It is impossible to know for sure what has happened here, but it is probably the case that the urban edge caught up with and overwhelmed farming at this site in the period 1988 to 1993 which only high value vertically integrated enterprises such as the Irene dairy farm could survive. This enterprise is still a working dairy but also offers a restaurant, coffee shop, deli, direct milk sales to the public and petting zoo which is very popular with you families in Centurion and surrounding areas. While we are not at all claiming that building up this kind of business will be impossible for land reform beneficiaries, we feel very strongly that the Irene dairy farm should not be used as indicator of median farm income in land reform projects. The change in the West was more gradual. Area farmed decreased by $8 \%$ in the period 1983 to 1988 , and then by $37 \%$ in the period between 1988 and 1993, and again by 48\% in the period between 1993 and 2002. It seems that here there has been less development pressure and a rural character survived more easily.

The data to calculate net farm income per hectare per year and purchase prices are given in Tables 3 and 4 . There have been substantial increases in real production costs over study period which will affect productive value negatively. The closest match for the census revenue data is the Computus Study Group figures (www.computus.co.za) which puts maize production costs for 2004/5 at R3,237 per hectare in 2010 prices. The corresponding cost estimate for cattle is R247 per hectare untransformed veld, assuming a stocking density of five hectares per LSU.

The net farm income per hectare presented in Table 4 subtracts the Computus cost estimates from the average and 2010 gross revenue figures obtained from the Census. The resulting average net farm income varied from -R300 per hectare for maize to R3,428 for cattle in Statistical Region 78. The 2002 figures varied from 
R2,419 per hectare for maize in Statistical Region 78 to over R10,000 per hectare for cattle at the same site. At a discount rate of $8 \%$ the net present value of cattle production based on average profitability was R38,892. The corresponding figure for Statistical Region 76 was approximately $50 \%$ lower. At a discount rate of $8 \%$ the estimated net present value for maize in Statistical Region 78 was -R3,377. In Statistical Region 76 the net present value of maize using a $8 \%$ discount rate was $R 27,266$. As present value of the expected future income stream these net present value estimates can be interpreted as the maximum price payable for farmland in the study area. According to Senwes productive values for farmland in 2012/13 prices for North West Province and Gauteng are about R2,548 per hectare for untransformed natural grazing and R12,000 for arable land. Since this analysis assumed a mixed farming system, we cannot really comment on the productive value rangelands. The estimate of R12,000 per hectare for arable land implies a price of R10,818 per hectare in 2010 prices, which in turn implies a discount rate of more than $20 \%$.

Table 3: Estimates of production costs for maize and cattle for Gauteng

\begin{tabular}{|c|c|c|}
\hline Source and description & Maize & Cattle \\
\hline \multicolumn{3}{|c|}{ Computus Study Group 5 year average, www.computus.co.za } \\
\hline $\begin{array}{l}\text { Nominal total allocated cost in R/ha for } 2004 / 5 \\
\text { Nominal total allocated cost in R/LSU for } 2004 / 05\end{array}$ & 2,242 & $\begin{array}{l}171 \\
854\end{array}$ \\
\hline Real cost in $\mathrm{R} / \mathrm{ha}$ in 2010 prices & 3,237 & 247 \\
\hline \multicolumn{3}{|c|}{ Enterprise budget for the Bothaville area, www.grainsa.co.za } \\
\hline Nominal total allocated cost in $\mathrm{R} / \mathrm{ha}$ for $2012 / 13$ & $\begin{array}{l}9,372 \\
8,114\end{array}$ & \\
\hline Real cost in $\mathrm{R} / \mathrm{ha}$ in 2010 prices & $\begin{array}{l}8,449 \\
7,315\end{array}$ & \\
\hline \multicolumn{3}{|c|}{ Enterprise budget for the Northern Cape, www.nkrpo.oc.za } \\
\hline $\begin{array}{l}\text { Nominal total allocated cost in R/ha for } 2011 / 12 \\
\text { Nominal total allocated cost in R/LSU for } 2004 / 05\end{array}$ & & $\begin{array}{l}130 \\
778\end{array}$ \\
\hline Real cost in $\mathrm{R} / \mathrm{ha}$ in 2010 prices & & 117 \\
\hline
\end{tabular}


Table 4: Productive values of land used to graze cattle or cultivate maize

\begin{tabular}{|c|c|c|c|c|c|}
\hline \multirow[b]{2}{*}{ Description } & \multirow[b]{2}{*}{ Year } & \multicolumn{2}{|c|}{ Statistical region 78} & \multicolumn{2}{|c|}{ Statistical region 76} \\
\hline & & Cattle & Maize & Cattle & Maize \\
\hline \multirow{5}{*}{$\begin{array}{l}\text { Gross revenue R/ha } 2010 \\
\text { prices }\end{array}$} & 1983 & 1,110 & 2,117 & 769 & 3,238 \\
\hline & 1988 & 2,046 & & 3,520 & 2,535 \\
\hline & 1993 & 1,240 & 1,038 & 262 & 2,323 \\
\hline & 2002 & 10,303 & 5,656 & 2,935 & 5,820 \\
\hline & avg & 3,675 & 2,937 & 1,872 & 3,479 \\
\hline \multirow{3}{*}{\multicolumn{2}{|c|}{$\begin{array}{l}\text { Production cost in } 2010 \mathrm{R} / \mathrm{ha} \\
\text { Average NFI in } 2010 \mathrm{R} / \mathrm{ha} \\
\mathrm{NFI} \text { for } 2002 \text { in } 2010 \mathrm{R} / \mathrm{ha}\end{array}$}} & 247 & 3,237 & 247 & 3,237 \\
\hline & & 3,428 & -300 & 1,625 & 2,422 \\
\hline & & 10,056 & 2,419 & 2,688 & 2,583 \\
\hline \multicolumn{6}{|c|}{ Productive values based on average income } \\
\hline \multirow[t]{2}{*}{ NPV over 30 years in $R /$ ha at } & $8 \%$ & 38,592 & $-3,377$ & 18,294 & 27,266 \\
\hline & $14 \%$ & 24,005 & $-2,101$ & 11,379 & 16,960 \\
\hline \multicolumn{6}{|c|}{$\begin{array}{l}\text { Land that can be bought with an LRAD grant plus compulsory own contribution at average } \\
\text { NFIs }\end{array}$} \\
\hline \multirow[t]{2}{*}{ R20,000 grant + R5,000 own } & $8 \%$ & 0.65 & & 1.37 & 0.92 \\
\hline & $14 \%$ & 1.04 & & 2.20 & 1.47 \\
\hline \multirow{2}{*}{$\begin{array}{l}\text { R100,000 grant }+R 400,000 \\
\text { own }\end{array}$} & $8 \%$ & 12.96 & & 27.33 & 18.34 \\
\hline & $14 \%$ & 20.83 & & 43.94 & 29.48 \\
\hline
\end{tabular}

The bottom section of Table 4 contains the number hectares that can be purchased with various sized LRAD grants plus the compulsory own contribution. Assuming a higher discount rate in the NPV calculation leads to lower productive values, but the number of hectares that can be purchased with the smallest LRAD was relatively insensitive to the discount rate chosen. According to our calculations a R20,000 LRAD grant plus its compulsory own contribution of R5,000 will in most cases buy the beneficiary less than two hectares of arable land in Gauteng. Even at the top end of the grant range, the sum of a R100,000 grant plus the compulsory R400,000 own contribution only buys in the order of about twenty to thirty hectares of arable land. This is while Senwes estimates the minimum viable farm size for the area to be 500 hectares (www.senwes.co.za ). It is therefore completely unsurprising 
that very little progress has been made with land redistribution to date (Vink and Hall, 2010).

However, before these results inspire direct policy action, it should be noted that underlying limitations in the data mean that the results are merely estimates and should not be taken as definitive truth. If such tools are to be utilized in the future, it is recommended that a more accurate statistical foundation be used, either through improved censuses or via more reliable methods in a more detailed study with a greater scope.

\section{CONCLUSION}

This paper constructed a set of stepwise demand functions using data from various census publications for Statistical Regions 76 and 78 for the years 1983, 1988, 1993 and 2002. Howe's method of demand function construction was applied to the gross value/hectare values which were the result of a number of estimation techniques and data cleaning methods. Horticultural products were found to be relatively high value, with tomatoes consistently holding the position of most valuable agricultural product. Field crops and area dedicated to livestock tended to be much lower in value, with livestock consistently being the lowest value activity, which, in general, takes up the majority of available agricultural land. Published cost data for maize and beef cattle imply productive values that where substantially larger than those reported by commercial agriculture and a comparison of productive values with the LRAD grants revealed that not even the biggest grant were remotely large enough to facilitate the purchase of a financially viable production unit.

The lack of consistency in the farm census reports, and the very limited scope of the most recent edition of the census is cause for concern. Furthermore the spurious estimates produced at the statistical region level makes one worry about the quality of the national estimate. It was a serious limitation to the current analysis that neither Statistics South Africa nor the Department of Agriculture and Forestry has attempted to publish enterprise budgets for the key commodity groups in agriculture for a while now. A transparent representative estimate of costs (and revenues) is an essential input into the estimation of productive values which everyone can trust. 
Knowing that that the government is aware of an acknowledges the proper productive value of land will increase confidence in the land reform project and will make for the kind of viable land reform programme which this country desperately needs.

\section{REFERENCES}

Attwood, E. A., Heavey, J. F. (1964) Determination of Grazing Livestock Units, Irish Journal of Agricultural Research, 3(2): 65-94.

Central Statistical Service, RSA (1998) Census of Agriculture: 1993, Pretoria.

Central Statistical Service, RSA (1993) Census of Agriculture: 1988, Pretoria.

Central Statistical Service, RSA (1987) Census of Agriculture: 1983, Pretoria.

Department of Agriculture, Forestry and Fisheries, RSA (2012) Abstract of Agricultural Statistics: 2012, Pretoria, http://www.daff.gov.za [Accessed: 3 March 2014].

Department of Agriculture, Forestry and Fisheries, RSA (1996) Abstract of Agricultural Statistics: 1996, Pretoria.

Howe, W. C. (1985) Economic, legal and hydrological dimensions of potential interstate water markets, American Journal of Agricultural Economis, 65(5): 1226-1230.

Jacobs, P., Lahiff, E., Hall, R. (2003) Land distribution. Paper 1 in "Evaluating Land and Agrarian Reform in South Africa", a PLAAS occasional paper series, UWC, Bellville.

Middelberg, S.L. (2014). Agricultural land valuation methods by financiers: The case of South Africa. Agrekon 53(3): 101-115

Statistics South Africa, RSA (2002) Provincial reports for Census: 2002, Pretoria, http://www.statssa.gov.za/agriculture/publications2007.asp [Accessed: 24 February 2014].

Vink, N. and Hall, R. (2010) Agricultural and land policy, in Jones, S and Vivian, R. (eds.) South African economy and policy, 1990-2000. Manchester: Manchester University Press. 
http://journals.uct.ac.za/index.php/UR

DOI 10.15641/ur-at-uct.v1i1.24

Williams, G., Ewert, J., Hamann, J. \& Vink, N. (1998) Liberalizing Markets and Reforming Land in South Africa, Journal of Contemporary African Studies, 16(1): 65-94. 